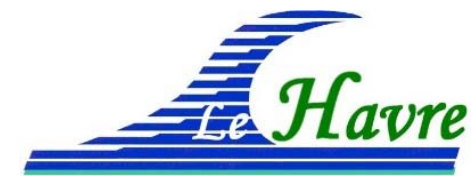

XVI èmes Journées Nationales Génie Côtier - Génie Civil

Le Havre, 2020

DOI:10.5150/jngcgc.2020.013 ～(C) Editions Paralia CFL

disponible en ligne - http://www.paralia.fr - available online

\title{
Wave-current interactions and infragravity waves at the Tagus Estuary mouth (Portugal)
}

\section{Baptiste MENGUAL ${ }^{1}$, Xavier BERTIN ${ }^{1}$, Marc PEZERAT ${ }^{1}$, Thibault COULOMBIER ${ }^{1}$, Diogo MENDES ${ }^{2,3,4}$, André Bustorff FORTUNATO ${ }^{3}$, Kévin MARTINS ${ }^{5}$, Rui TABORDA ${ }^{6}$}

\section{UMR 7266 LIENSs CNRS-La Rochelle Université, 2 rue Olympe de Gouges, La} Rochelle, France.baptiste.mengual@univ-lr.fr

2. CERIS, Instituto Superior Técnico, Universidade de Lisboa, Av. Rovisco Pais, 1, Lisbon, Portugal.

3. National Laboratory for Civil Engineering, Av. do Brasil, 101, Lisbon, Portugal.

4. Hydrographic Institute, Rua das Trinas, 49, Lisbon, Portugal.

5. UMR 5805 EPOC CNRS-Université de Bordeaux, Allée Geoffroy Saint-Hilaire, Pessac, France.

6. Instituto Dom Luiz, University of Lisbon, 1749-016, Lisbon, Portugal

\begin{abstract}
:
Estuary mouths subject to tides and waves generally exhibit complex hydrodynamics and sediment transport patterns where waves and currents interact, making the morphology of these coastal systems highly dynamic. Although they concentrate numerous socioeconomic and environmental issues, their hydro-sedimentary dynamics remains only partly understood, in particular for the part exposed to ocean waves. This paper describes hydrodynamic measurements acquired over the Tagus Estuary mouth, one of the largest in Europe, during energetic winter conditions. The analysis of field data provides evidence for substantial tidal modulations of bulk wave parameters caused by water depth changes (e.g. wave energy dissipation by depth-induced breaking) and alternating currents (dissipation of high frequencies due to opposing currents during the ebb). In addition, measurements reveal interesting features with respect to infragravity waves, whose behaviour significantly varies between offshore (i.e. outside of breaking areas) and nearshore mooring stations. In particular, a substantial increase of their average period is highlighted during energetic conditions (up to 4-5 minutes) at a nearshore station located at the estuary entrance. According to recent findings conducted on a dissipative beach, a plausible explanation would be the merging of infragravity waves, due to the combination of free and bound waves across the several kilometre-wide surf zone. The development of such long period IG waves could provide an explanation for the frequent and intense coastal flooding events reported by inhabitants of a neighbourhood, Segundo Torrão, located at this specific site.
\end{abstract}

\section{Keywords:}

Wave-current interactions, Infragravity waves, Hydrodynamic measurements. 


\section{Thème 1 - Hydrodynamique côtière}

\section{Introduction}

Due to their attractiveness, estuaries and their adjacent coasts concentrate many socioeconomic and environmental issues such as erosion and coastal flooding risks, the management of sediment resources or the ecosystem preservation (e.g. water quality, nutrients, habitats). Estuaries exposed to the combined action of waves and tides exhibit complex hydrodynamics and highly-dynamic morphologic changes, whose governing processes are still not fully understood. Most studies on wave-current interactions were based on a modelling approach and concerned small to medium tidal inlet systems (e.g. BERTIN et al., 2009; DODET et al., 2013), and only a few were dedicated to larger mouth systems (e.g. RUSU et al., 2011; ZIPPEL \& THOMSON, 2017). In case of large estuary mouth, the literature on field observations remains scarce, in particular during energetic conditions due to difficulties in deploying and retrieving instruments. Furthermore, recent studies highlighted that infragravity waves (long waves due to the presence of groups in incident waves) could develop across wide surf zones during energetic conditions. Their relevance in the seasonal closure of wave-dominated tidal inlets has also been demonstrated (BERTIN et al., 2019). This study aims at investigating nearshore wave propagation from field observations, including short and infragravity waves (hereafter SW and IGW, respectively), and their tidal modulations at the Tagus Estuary mouth during energetic conditions. This work is part of a citizen-science project (named Nouveaux Commanditaires Sciences; see Acknowledgments), whose research program has been set up following the request for a better understanding of the coastal erosion and marine flooding during storms. This request was expressed by severely affected inhabitants from an informal neighbourhood, Segundo Torrão (figure 1b; location PS_Torrao), who provide support for instrumental deployments and data acquisitions. The manuscript is organised as follows. The study site, field experiments and data analyses are presented in section 2. Results associated to field observations are presented and discussed in sections 3 and 4, respectively.

\section{Field campaign and data analysis}

\subsection{Brief description of the study site}

The Tagus Estuary, located on the west coast of Portugal, is one of the largest estuaries in Europe with a surface of around $320 \mathrm{~km}^{2}$. The Atlantic Ocean connects to a shallow tide-dominated basin through a deep, long and $2 \mathrm{~km}$-wide tidal inlet (figure 1). The continental shelf width is around $40 \mathrm{~km}$ in front of the mouth. The Tagus Estuary mouth is a semi-diurnal meso-tidal environment characterised by tidal ranges varying from 0.55 to more than $3.86 \mathrm{~m}$ at the coast (GUERREIRO et al., 2015), and by a strong dominance of the ebb (FORTUNATO et al., 1999). The wave regime is dominated by long-period swells generated in the North Atlantic Ocean. During the winter, offshore mean wave 


\section{XVİ̀mes Journées Nationales Génie Côtier - Génie Civil \\ Le Havre 2020}

conditions correspond to significant wave heights of $2.5 \mathrm{~m}$, peak periods of $12.1 \mathrm{~s}$ and a mean wave direction of $305^{\circ}$ (DODET et al., 2010). Therefore, the Tagus Estuary is highly exposed to waves, which play a key role in its hydrodynamics, display strong interactions with currents (RUSU et al., 2011), and can contribute to storm surges at the scale of the whole basin (FORTUNATO et al., 2017). Lastly, complex bed morphologies are found at the mouth with an extensive ebb-delta shoal, the Bugio Bank (figure 1b), and with bed sediments mainly composed of medium sands (FREIRE et al., 2007).
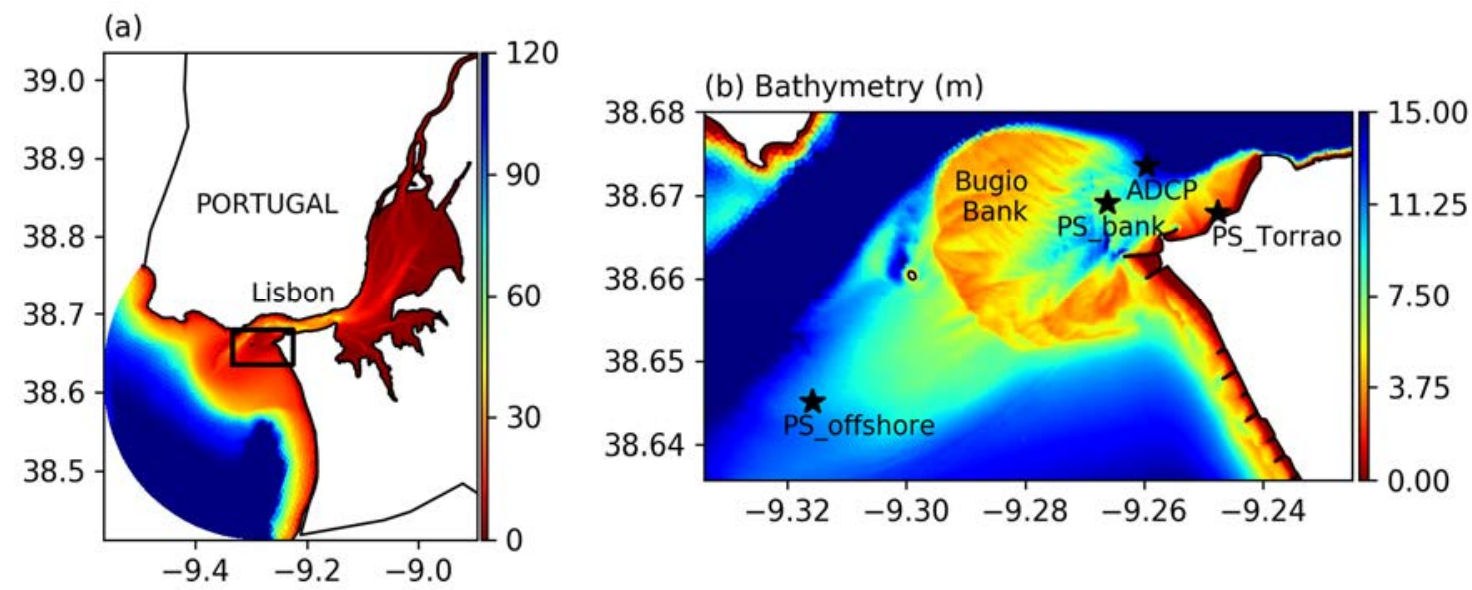

Figure 1. (a) Study site and its bathymetry (in $\mathrm{m}$ ) with respect to mean sea level (2.26 m above chart datum) and (b) zoom on the Bugio Bank with locations of instruments indicated by black stars.

\subsection{Field experiment}

Three RBR pressure sensors and one $600 \mathrm{kHz}$ ADCP (Acoustic Doppler Current Profiler) were deployed at the estuary mouth during one week (from the $16^{\text {th }}$ to $24^{\text {th }}$ November, 2019), during which an energetic event occurred with offshore wave heights $\left(H_{m 0}\right)$ and peak periods $\left(T_{p}\right)$ reaching $6 \mathrm{~m}$ and $20 \mathrm{~s}$ (source: Portuguese Hydrographic Institute). From offshore to nearshore locations, sensors PS_offshore (-9.316; 38.645), PS_bank ($9.266 ; 38.67)$ and PS_Torrao $(-9.247 ; 38.668)$ were respectively deployed at mean water depths of $10.6 \mathrm{~m}, 5.8 \mathrm{~m}$ and $2.8 \mathrm{~m}$ (figure 1b). PS_offshore and PS_bank were fixed to anchors directly deployed on the seabed whereas PS_Torrao was hooked up to a pillar, at $1.65 \mathrm{~m}$ above the seabed. Continuous pressure measurements were made at a sampling frequency of $2 \mathrm{~Hz}$. The ADCP (-9.26; 38.673; mean water depth of $10.24 \mathrm{~m})$, was set in an up looking configuration with $0.50 \mathrm{~m}$-thick cells, providing average current profiles every 30 minutes and 20-minute bursts of pressure measurements every hour (at $2 \mathrm{~Hz}$ ). Unfortunately, ADCP measurements are only available over the first 1.5 days of the field campaign, due to a malicious act. 


\section{Thème 1 - Hydrodynamique côtière}

\subsection{Data processing}

To assess wave bulk parameters, pressure time series recorded at PS_offshore, PS_bank and PS_Torrao were split into 1 hour-long bursts, corrected from atmospheric pressure and detrended. Then, the free surface elevation was reconstructed using the Transfer Function Method based on linear wave theory (TFM; e.g. BISHOP \& DONELAN, 1989) at PS_offshore, and the weakly dispersive nonlinear method described by BONNETON et al. (2018) at PS_bank and PS_Torrao, which enables to derive elevation of nonlinear waves propagating in shallow water. To exclude the noisy part of the signal, the reconstruction methods require the definition of an upper cut-off frequency, $f_{\text {max }}$, which was fixed at $0.3 \mathrm{~Hz}$ for all pressure sensors. The elevation variance spectra $E(f)$ associated to frequencies $f$ were computed by applying a Fast Fourier Transform and by considering 10 Hanning-windowed segments (with an overlap of 50\%), leading to a frequency resolution of $0.003 \mathrm{~Hz}$. From each spectrum, wave parameters can be computed using the $p$-th moments, $m_{p}$, that correspond to the integration of $f^{p}$.E(f).df between two cut-off frequencies, $f_{\min }$ and $f_{\max }$. Thus, significant wave height $H_{m 0}$ can be computed as $4 \times\left(m_{0}\right)^{0.5}$ and the mean wave period $T_{m 02}$ as $\left(m_{0} / m_{2}\right)^{0.5}$. According to ROELVINK \& STIVE (1989), an adaptive $f_{\min }$ value was defined as half of the continuous peak frequency, $f_{p c}=\left(\mathrm{m}_{0}\right)^{2} /(\mathrm{m}$ 2. $m_{1}$ ), firstly derived between 0.04 and $0.4 \mathrm{~Hz}$ (i.e. in the gravity band). Such an adaptive lower cut-off frequency, hereinafter $f_{\min , S W}$, enables a more accurate distinction between infragravity and gravity bands of spectra, according to the maximum energy frequency. Finally, wave parameters associated to $\mathrm{SW}, \mathrm{H}_{\mathrm{m} 0, \mathrm{SW}}$ and $\mathrm{T}_{\mathrm{m} 02, \mathrm{SW}}$, are derived by integrating spectra between $f_{\min , S W}$, and $f_{\max }$, while those associated to IGW, $H_{m 0, I G W}$ and $T_{m 02, I G W}$, are integrated until $f_{\min , S W}$.

\section{Results}

\subsection{Short waves}

Temporal evolution of SW parameters $H_{m 0, S W}, T_{m 02, S W}$ and $T_{p}$ (figure $2 \mathrm{~b}, \mathrm{c}, \mathrm{d}$ ) highlight that the deployment period is characterised by calm conditions at the beginning, followed by an energetic period with $H_{m 0, S W}$ values reaching almost $4 \mathrm{~m}$ at PS_offshore. At this location, the tidal modulation of mean wave parameters substantially differs with the one observed at other locations. While no significant modulation is observed for $H_{m 0, S W}<1$ $\mathrm{m}$, a pronounced increase in $H_{\mathrm{m} 0, \mathrm{SW}}$ is highlighted at low tide for moderate to energetic conditions. In particular, the three low tides starting from the $20^{\text {th }}$ of November are characterized by very strong $H_{m 0, S w}$ increases, reaching up to $1 \mathrm{~m}$ compared to the high tide situation (i.e. between $+30 \%$ and $+50 \%$ ). It is interpreted that low water levels promote wave refraction over the western part of the Bugio Bank. Over the whole period, $\mathrm{H}_{\mathrm{m} 0 \text {,Sw }}$ at low tide are on average $16 \%$ higher than during high tide at PS_offshore. Note that $T_{m 02, S w}$ exhibits a marked tidal modulation during the most energetic period, with an increase during the flood and a decrease during the ebb (+/- $2 \mathrm{~s})$. 


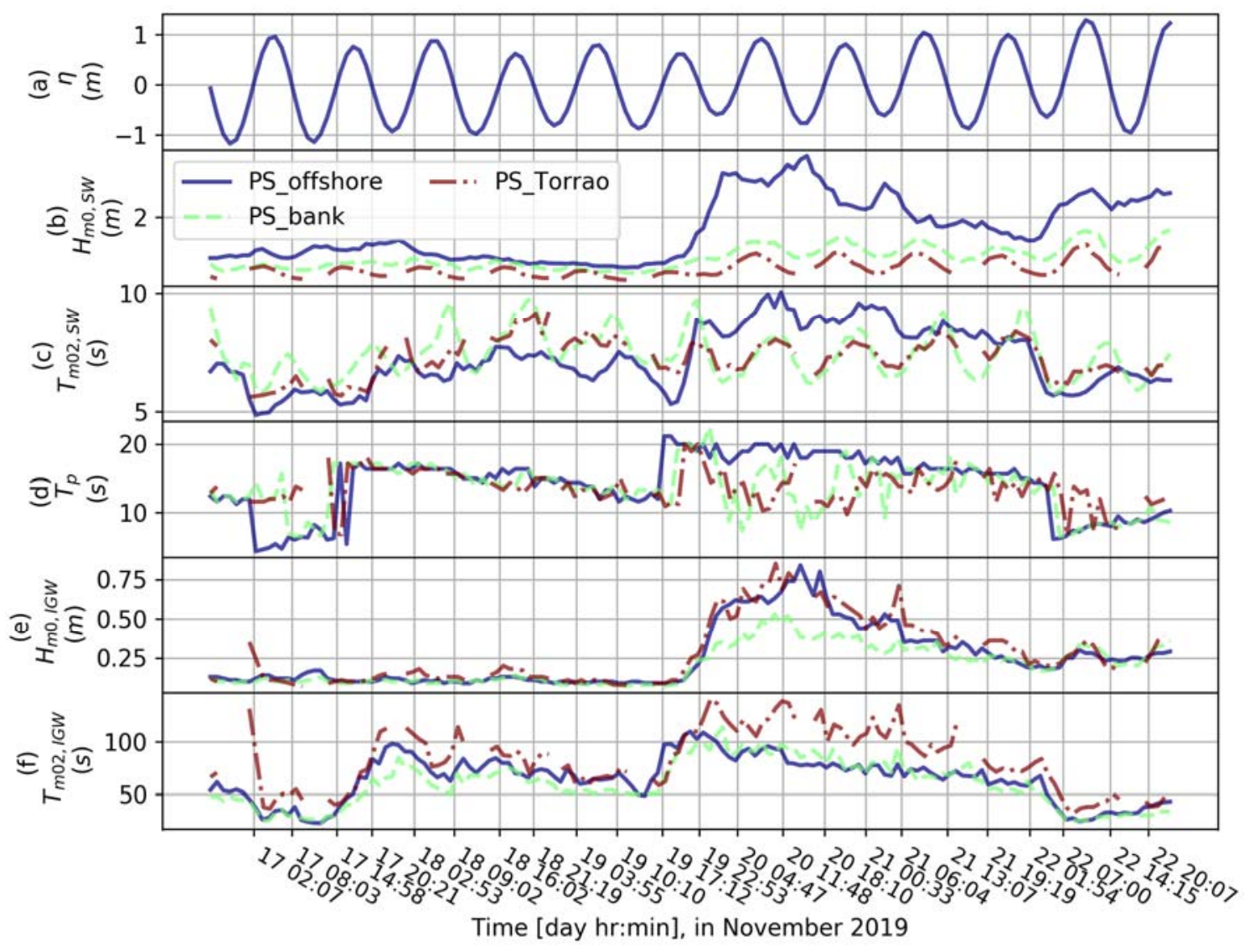

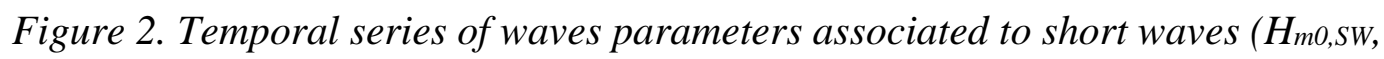

$\left.T_{m 02, S W}, T_{p}\right)$ and infragravity waves ( $\left.\mathrm{H}_{\mathrm{m} 0, \mathrm{IGW}}, \mathrm{T}_{\mathrm{m} 02, \mathrm{IGW}}\right)$, measured at the different stations. Water elevations around the mean sea level $\eta$ on (a) are taken at PS_offshore.

At PS_bank, located at the NE part of the Bugio Bank, a very strong tidal modulation is observed. First, $\mathrm{H}_{m 0, S W}$ and $\mathrm{T}_{\mathrm{m} 02, \mathrm{SW}}$ at high tide are $48 \%$ and $18 \%$ higher than during the low tide, respectively (figures $3 \mathrm{a}$ and $3 \mathrm{~b}$ ). This behaviour is explained by more intense wave energy dissipation due to depth-limited breaking over the Bugio Bank at low tide. Moreover, substantial differences can be underlined between the flood and the ebb, by considering similar water depths. During the flood, $H_{m 0, S w}$ are on average $19 \%$ higher whereas $T_{m 02, S W}$ and $T_{p}$ are respectively $20 \%$ and $15 \%$ lower (see $H_{m 0, S W}$ and $T_{m 02, S W}$ correlations on figures $3 \mathrm{c}$ and $3 \mathrm{~d}$ ). This can be attributed to current effects on the wave field propagation. Indeed, the presence of a tidal secondary channel on figure 1 suggests strong tidal currents over this region, as those measured at the ADCP location. ADCP data (not shown) reveal pronounced currents, oriented SW-NE, with velocities around 0.7 $\mathrm{m} / \mathrm{s}$ during the flood and reaching up to $1 \mathrm{~m} / \mathrm{s}$ during the ebb.

Similar conclusions can be drawn at PS_Torrao, located more inside of the estuary, where waves are expected to have experienced more transformation and dissipation. On the one 


\section{Thème 1 - Hydrodynamique côtière}

hand, $H_{m 0, S W}$ and $T_{m 02, S W}$ at high tide are on average 2.5 times and $12 \%$ higher than during low tide. On the other hand, at mid-flood, $\mathrm{H}_{m 0, S w}$ are on average $88 \%$ higher than at midebb, whereas wave periods are generally 15 to $20 \%$ lower. Indeed, a marked reduction of the wave energy associated to high frequencies $(f>0.2 \mathrm{~Hz})$ is observed during the ebb, that is, when strong currents oppose wave propagation. Thus, it is interpreted that opposing currents make very short waves break by increasing their steepness, which reduces $H_{m 0, S W}$ but increases the average period $T_{m 02, S W}$.
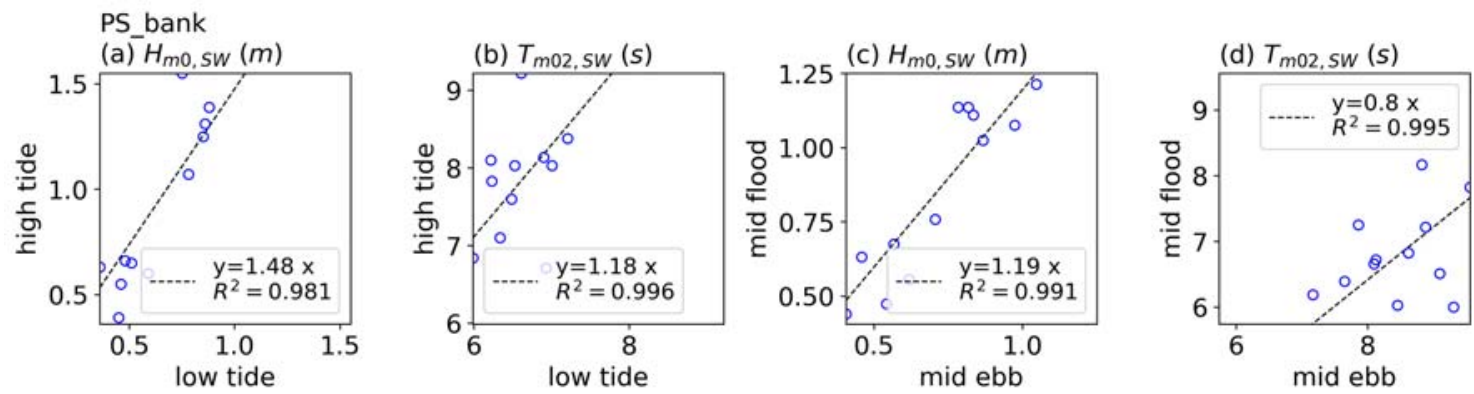

Figure 3. Correlations between $S W$ bulk parameters $\left(H_{m 0, S w}\right.$ or $\left.T_{m 02, S W}\right)$ observed during successive high and low tides, or mid-flood and mid-ebb phases (circles) at PS_bank.

Dotted lines depict linear regressions and $R^{2}$ refers to determination coefficients.

\subsection{Infragravity waves}

At PS_offshore, IGW are weakly influenced by water depth and current variations caused by tides (figure 2e,f). Indeed, this sensor is probably located outside of areas subject to wave breaking or intense circulations. $H_{m 0, I G W}$ are lower than $0.2 \mathrm{~m}$ during calm periods and vary between 0.5 and $0.85 \mathrm{~m}$ during more energetic conditions. Their mean periods mainly vary from 50 to $100 \mathrm{~s}$.

A decrease of $H_{m 0, I G W}$ is observed from PS_offshore to PS_bank. It may mean that, on the one hand, IGW experience many transformations over the Bugio Bank, and on the other hand, that these two stations are not perfectly aligned with the mean wave direction. At PS_bank, $H_{m 0, I G W}$ and $T_{m 02, I G W}$ are relatively similar between mid-flood and mid-ebb, considering similar water depths. This indicates that, unlike SW, their propagation does not seem to be influenced by tidal currents. However, they appear to be more affected by water depth changes. $H_{m 0, I G W}$ at high tide are on average $17 \%$ higher than during the low tide situation. This behaviour agrees with previous remarks suggesting a dependency of IGW to transformations experienced by SW groups over the Bugio Bank (evoked to explain differences between PS_offshore and PS_bank).

At PS_Torrao, $H_{m 0, I G W}$ are generally higher than at PS_offshore $(+16 \%$ on average). Compared to the offshore site, substantial increases in $T_{m 02, I G W}$ values are observed throughout the period $(+30 \%$ on average; figure $2 \mathrm{f})$, in particular during energetic conditions (up to $+90 \%$ ). Regarding the tidal modulation, for similar water depths, $H_{m 0, I G W}$ (resp. $T_{m 02, I G W}$ ) is on average $10 \%$ higher (resp. lower) during mid-flood 


\section{XVIèmes Journées Nationales Génie Côtier - Génie Civil \\ Le Havre 2020}

compared to the mid-ebb situation, that may be due to SW transformations or refraction by tidal currents. At high tide, $H_{m 0, I G W}$ (resp. $T_{m 02, I G W}$ ) is on average $15 \%$ higher (resp. lower) than during low tide. Dealing with IGW, one of the most noteworthy results holds in the strong increase of $T_{m 02, I G W}$ highlighted at PS_Torrao during the energetic period in comparison with observations at other stations (figure $2 \mathrm{f}$; between the $19^{\text {th }}$ at $11 \mathrm{pm}$ and the $21^{\text {st }}$ at $\left.6 \mathrm{am}\right)$. Focusing on the peak of the energetic period $\left(20^{\text {th }}\right.$ November at $\left.2 \mathrm{pm}\right)$, figure 4 provides evidence for long-period IGW (period reaching 4-5 minutes) at PS_Torrao, not observed at the offshore site. Note that, due to its location, the incoming wave energy is frequently dominant in the infragravity band during energetic conditions. Actually, the pressure sensor at Segundo Torrão was deployed over a two-month period (from the $25^{\text {th }}$ October to the $27^{\text {th }}$ December 2019), including several major storms such as Fabien (22 ${ }^{\text {nd }}$ December), during which $H_{m 0, I G W}$ associated to IGW appeared to be dominant over $\mathrm{SW}$, and reached up to $1.5 \mathrm{~m}$. The mechanism expected to contribute to the development of these long-period IGW during energetic conditions is discussed in section 4 .

(a) PS_offshore
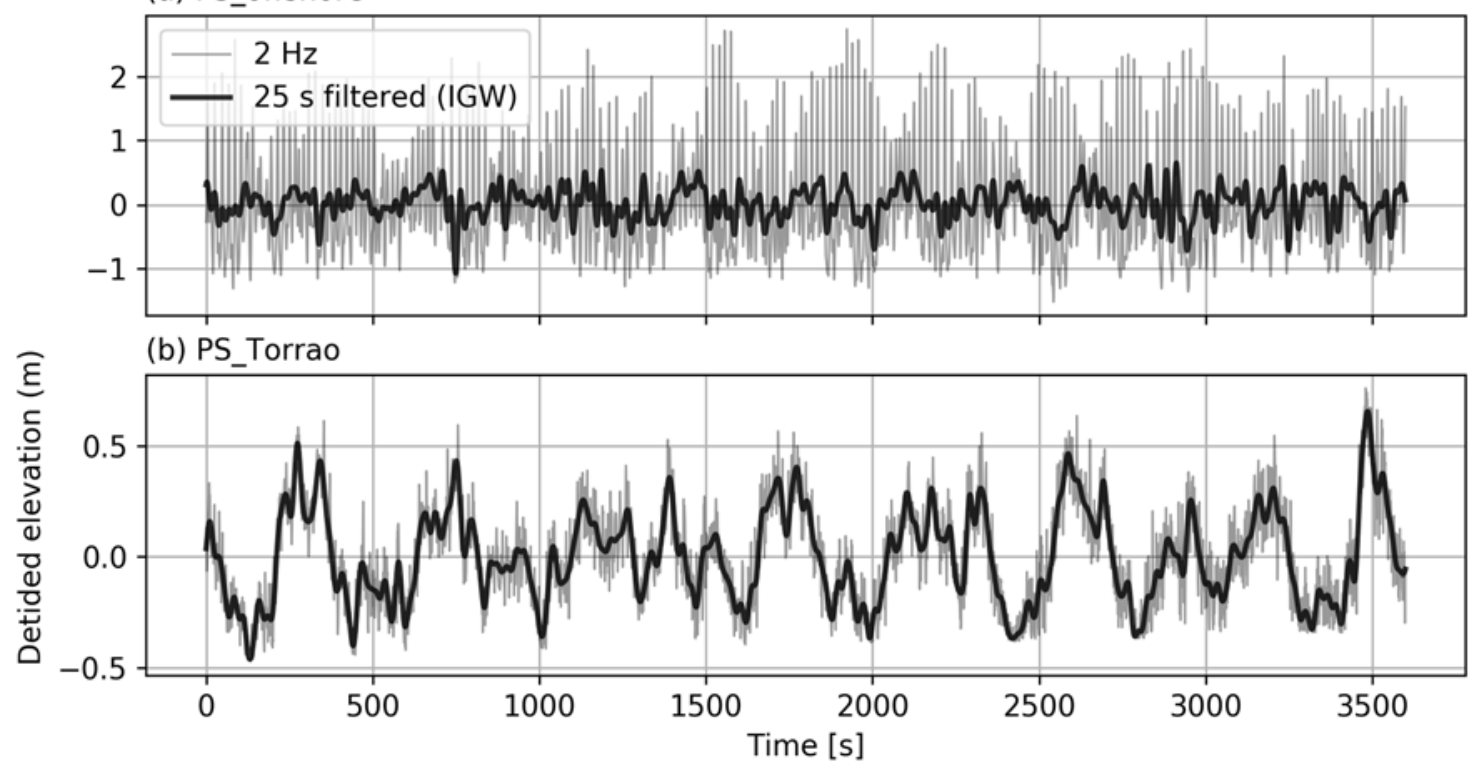

Figure 4. Detided elevations obtained at the peak of the energetic period (1-hour series starting from the $20^{\text {th }}$ November at $2 \mathrm{pm}$ ) at PS_offshore (a) and PS_Torrao (b). Thick black lines refer to infragravity waves, obtained by filtering all periods lower than $25 \mathrm{~s}$.

\section{Discussion and concluding remarks}

New field observations collected at the mouth of the Tagus Estuary under storm waves highlight a substantial tidal modulation of short waves bulk parameters, including first dissipation induced by depth-limited breaking over the Bugio Ebb-delta depending on water levels, in agreement with previous findings reported on wave-current interactions 


\section{Thème 1 - Hydrodynamique côtière}

at the mouth of tidal inlets (e.g. OLABARRIETA et al., 2011). In addition, present results reveal that the combination of dissipation due to depth-limited breaking and strong opposing currents during the ebb induces a sharp reduction of the wave energy in the high frequency part of the wave spectrum, which results in a marked decrease (resp. increase) of wave heights (resp. periods) compared to the flood phase. Indeed, intense currents oriented SW-NE and reaching up to $1 \mathrm{~m} / \mathrm{s}$ have been measured at the estuary mouth (ADCP location), in agreement with hydrodynamic circulations reported in the literature (FORTUNATO et al., 1997). Under strong opposing currents, it is generally mentioned that the wave energy propagation can be partly or completely blocked (e.g. OLABARRIETA et al., 2011; ARDHUIN et al., 2012). Ebb currents are commonly identified to promote wave steepness and enhance wave breaking. During energetic conditions, low water levels probably promote wave refraction over the western part of the Bugio Bank (PS_offshore), which leads to an increase of short wave heights up to 1 $\mathrm{m}$ at low tide. This indicates some significant variations of the wave breaking point and consequently of the surf zone width depending on tidal oscillations. Thus, substantial modulations of short waves properties by tidal-induced water depth and current variations have been highlighted over the Tagus Estuary mouth.

Regarding infragravity waves, according to BERTIN et al. (2020), the development of several kilometric-wide surf zones could promote the formation of long-period infragravity waves through the merging of bound and free waves. Infragravity waves measured at Segundo Torrão with periods of 4 to 5 minutes may result from similar processes and could explain coastal flooding events reported by local populations during storms. Indeed, the formation of long-period IGW (strong increase of $T_{m 02, I G W}$ towards the coast) occurs during energetic incident wave conditions, which results in the development of a very large surf zone over the Bugio Bank, maximum in the alignment of Segundo Torrão. To our knowledge, such long-period infragravity waves have never been observed at the scale of a wide estuary like the Tagus during energetic conditions. This suggests that infragravity waves can be a relevant process influencing the hydrodynamics of wave-exposed estuaries.

To go further regarding the implications of wave-current interactions and infragravity waves on the overall hydro-sedimentary dynamics, numerical simulations will be performed using a 3D model based on the full coupling between circulation, waves and sediment transport. Indeed, fully coupled modelling systems were shown to be powerful tools to investigate physical processes as those discussed in this study (e.g. OLABARRIETA et al., 2011; DODET et al., 2013). For instance, the effect of tidal currents can be switched off in the wave model. These future researches will aim at improving our understanding of physical processes controlling the Tagus Estuary hydrodynamics, and their consequences on sediment transport and morphodynamics, since both wave-current interactions and infragravity waves have already been identified 


\section{XVİ̀mes Journées Nationales Génie Côtier - Génie Civil \\ Le Havre 2020}

as major contributors of sediment dynamics over small tidal inlets (DODET et al., 2013; BERTIN et al., 2019).

\section{Acknowledgments}

This study was funded by the Fondation de France and Fondation Edouard et Geneviève Buffard. Authors greatly acknowledge other contributors involved in the collaborative project "Nouveaux Commanditaires Science", including Livio Riboli-Sasco (project coordinator; Atelier des Jours à Venir), João Cão (Center for Philosophy of Sciences, University of Lisbon) and Tatiana Arquizan (Canto do Curió Cultural Association, Lisbon), who initiated and manage the project in collaboration with local populations. Inhabitants from Segundo Torrão and Cova do Vapor are deeply thanked for their support on the field, especially the fisherman Toni Graça who provided a boat and his site experience during field campaigns. Lastly, bathymetric data were provided by the Portuguese Environmental Agency.

\section{References}

ARDHUIN F., ROLAND A., DUMAS F., BENNIS A.-C., SENTCHEV A., FORGET P., WOLF J., GIRARD F, OSUNA P., BENOIT M. (2012). Numerical wave modeling in conditions with strong currents: dissipation, refraction and relative wind. J. Phys. Oceanogr., Vol. 42, pp 2101-2120. https://doi.org/10.1175/JPO-D-11-0220.1

BERTIN X., FORTUNATO A.B., OLIVEIRA A. (2009). A modeling-based analysis of processes driving wave-dominated inlets. Continental shelf Research, Vol. 144, pp 5064. https://doi.org/10.1016/j.csr.2008.12.019

BERTIN X., OLABARRIETA M. (2016). Relevance of infragravity waves at a wavedominated inlet. Journal of Geophysical Research, Vol. 212, pp 5418-5435. https://doi.org/10.1002/2015JC011444

BERTIN X., MENDES D., MARTINS K., FORTUNATO A.B., LAVAUD L. (2019). The closure of a shallow tidal inlet promoted by infragravity waves. Geophys. Res. Lett. Vol. 46, pp 6804-6810. https://doi.org/10.1029/2019gl083527

BERTIN X., MARTINS K., DE BAKKER A., CHATAIGNER T., GUERIN T., COULOMBIER T., DE VIRON O. (2020). Energy transfers and reflection of infra gravity waves at a dissipative beach under storm waves. Journal of Geophysical Research: Oceans, Vol. 125. https://doi.org/10.1029/2019JC015714

BISHOP C.T., DONELAN M.A. (1989). Measuring waves with pressure transducers. Coastal Engineering, Vol. 12 (4), pp 381 - 384. https://doi.org/10.1016/0378-3839(89)90014-8 BONNETON P., LANNES D., MARTINS K., MICHALLET H. (2018). A nonlinear weakly dispersive method for recovering the elevation of irrotational surface waves from pressure measurements. Coastal Engineering, Vol. 138, pp 1-8. https://doi.org/10.1016/j.coastaleng.2018.04.005 


\section{Thème 1 - Hydrodynamique côtière}

DODET G., BERTIN X., TABORDA R. (2010). Wave climate variability in the NorthEast Atlantic Ocean over the last six decades. Ocean Modelling, Vol. 31, pp 120-131. https://doi.org/10.1016/j.ocemod.2009.10.010

DODET G., BERTIN X., BRUNEAU N., FORTUNATO A.B., NAHON A., ROLAND A. (2013). Wave-current interactions in a wave-dominated tidal inlet. Journal of Geophysical Research - Oceans, Vol. 118, pp 1587-1605. https://doi.org/10.1002/jgrc.20146 FORTUNATO A. B., BAPTISTA A. M, LUETTICH R. A. Jr. (1997). A threedimensional model of tidal currents in the mouth of the Tagus estuary. Continental Shelf Research, Vol. 17, pp 1689-1714. https://doi.org/10.1016/S0278-4343(97)00047-2 FORTUNATO A.B., OLIVEIRA A., BAPTISTA A.M. (1999). On the effect of tidal flats on the hydrodynamics of the Tagus estuary. Oceanologica Acta, Vol. 22/1, pp 31-44. https://doi.org/10.1016/s0399-1784(99)80030-9

FORTUNATO A.B., FREIRE P., BERTIN X., RODRIGUES M., FERREIRA J., LIBERATO M.L. (2017). A numerical study of the February 15, 1941 storm in the Tagus estuary. Continental Shelf Research, Vol. 144, pp 50-64. https://doi.org/10.1016/j.csr.2017.06.023 FREIRE P., TABORDA R., SILVA A. (2007). Sedimentary characterization of Tagus estuarine beaches (Portugal). A contribution to the sediment budget assessment. J. Soils Sediments, Vol. 7/5, pp 296-302. https://doi.org/10.1065/jss2007.08.243

GUERREIRO M., FORTUNATO A.B., FREIRE P., RILO A., TABORDA R., FREITAS M.C., ANDRADE C., SILVA T., RODRIGUES M., BERTIN X., AZEVEDO A. (2015). Evolution of the hydrodynamics of the Tagus estuary (Portugal) in the 21st century. Rev. Gest. Coste. Integr., Vol. 15/1, pp 65-80. https://doi.org/10.5894/rgci515 OLABARRIETA M., WARNER J.C., KUMAR N. (2011). Wave-current interaction in Willapa Bay. J. Geophys. Res., Vol. 116, pp C12014. https://doi.org/10.1029/2011JC007387 ROELVINK D.J.A, STIVE M. (1989). Bar-generating cross-shore flow mechanisms on a beach. Journal of Geophysical Research - Atmospheres, Vol. 94(C4), pp 4785-4800. https://doi.org/10.1029/JC094iC04p04785

RUSU L., BERNARDINO M., GUEDES SOARES C. (2011). Modelling the influence of currents on wave propagation at the entrance of the Tagus estuary. Ocean Engineering, Vol. 38(10), pp 1174-1183. https://doi.org/10.1016/j.oceaneng.2011.05.016

ZIPPEL S., THOMSON J. (2017). Surface wave breaking over sheared currents: observations from the mouth of the Columbia River. Journal of Geophysical Research Oceans, Vol. 112, pp 3311-3328. https://doi.org/10.1002/2016JC012498 